\title{
Justifying Resistance to Immigration Law: The Case of Mere Noncompliance
}

Caleb Yong

\section{The political ethics of immigration: justifying resistance}

There is now a flourishing debate on the philosophy of immigration law and policy. Within this debate, however, the focus has predominantly been on what John Rawls calls "principles which apply to institutions," to the relative neglect of "principles for individuals" — the principles that comprise what we might call the political ethics of immigration. Rather than asking how the institutions that regulate immigration should be structured, the political ethics of immigration asks how individuals should act towards prevailing institutions.

At the broadest level, the political ethics of immigration must determine whether individuals should practically accept institutions regulating immigration, or whether they should instead resist those institutions. ${ }^{2}$ Practical acceptance involves allowing one's conduct to be regulated by institutional rules and directives. This is crucially distinct from substantively assenting to or endorsing institutional rules. For this reason, contestation - acting to promote the repeal or reform a law or policy one disagrees with - can be perfectly consistent with practical acceptance. For example, an individual might use legally permitted means to oppose an immigration law she dissents from, even while abiding by its directives as long as it remains legally valid. Similarly, when individual citizens who occupy some official role in the monitoring and enforcement of immigration law act to mitigate the impact of a specific immigration law they object to by exercising their legally recognized powers of official discretion, their actions are again consistent with practical acceptance. ${ }^{3}$

By contrast, resistance involves a refusal to regulate one's conduct by prevailing institutional rules and directives. Resistance can be undertaken both by would-be migrants and by existing citizens of a receiving state. ${ }^{4}$ The former will be directed at primary immigration law, that is, the regime of laws

This paper has been greatly improved by the comments and suggestions of Nate Adams, James Christensen, Adam Hosein, David Miller, and Stefan Schlegel. For helpful discussion, I am also grateful to Guy Aitchinson, Benedikt Buechel, Michael Blake, Rahul Sagar, Ayelet Shachar, and audiences at the European University Institute and NYU Abu Dhabi. Research for this article was made possible by a fellowship at the Ethics, Law, and Politics Department of the Max Planck Institute for the Study of Religious and Ethnic Diversity.

1. John Rawls, A Theory of Justice (Harvard University Press, 1971) at 108.

2. See Philip Pettit, On the People's Terms (Cambridge University Press, 2012) at 136-40.

3. On the official discretion legally open to immigration agents in enforcing immigration law in the US context, and the significance of such discretion in mitigating the effects of unjust immigration laws, see Hiroshi Motomura, Immigration Outside the Law (Oxford University Press, 2014) at 26.

4. I use the term "citizen" broadly to include settled noncitizen residents who may also be addressed by secondary immigration law. Citizens of a state in this broad sense I will also refer to as "members" of that state. 
that regulates noncitizens' entry into and residence in a receiving state's territory. Would-be migrants' resistance can take several forms. The most radical would be revolutionary activity aimed at dismantling existing arrangements for the enactment, application, and enforcement of immigration law, namely arrangements whereby each independent state unilaterally wields the power to regulate immigration to its territory. Would-be migrants might also use violent means to actively repel immigration monitoring and enforcement efforts by the receiving state's agents. At the most basic level, individual would-be migrants can nonviolently refuse compliance with the directives of primary immigration law. For example, they can enter a state's territory without authorization, nonviolently escaping monitoring and enforcement efforts by deception. Such nonviolent breaches of immigration law I call mere noncompliance to distinguish them from instances of noncompliance that involve the use of force or that aim at a revolutionary outcome. ${ }^{5}$

For citizens of a receiving state, the target of their resistance will be secondary immigration law, that is, the regime of laws that directs certain individuals among a receiving state's existing citizenry to participate in or contribute to the implementation - the application and enforcement - of their state's primary immigration law. Again, resistance can take several forms. At a basic level, individual citizens might resist their state's secondary immigration law by nonviolently refusing compliance with secondary immigration law. For example, a social services provider may refuse to comply with immigration reporting requirements, or an employer may knowingly hire workers with forged work permits. Given that a single citizen's mere noncompliance will typically have little effect on the capacity of her state to implement its primary immigration law, an individual citizen might go further in destabilizing or disabling her state's immigration monitoring and enforcement mechanisms by actively blocking other citizens 'participation in such efforts. Finally, citizens might undertake revolutionary activity to overthrow and radically remake their state's existing institutions for regulating immigration.

I hope, in this article, to advance our understanding of when and why resistance to immigration law is morally justified. My focus will be circumscribed in two ways. First, I consider only the basic case of mere noncompliance, whether with primary or secondary immigration law. Because other forms of resistance typically involve the use of coercion or violence, their overall justifiability depends on further criteria governing the use of force, such as whether their targets are morally liable to attack, and whether the force used is necessary and proportionate. ${ }^{6}$ By focusing here on the justifiability of mere noncompliance, I bracket the thorny questions surrounding whether and how these criteria apply.

5. I take violence to be actions that use, or threaten to use, force against others.

6. For an overview of the criteria governing the central case of the justified use of force, namely self-defensive force, see Christian Coons \& Michael Weber, "The Ethics of Self-Defense: The Current Debate" in Christian Coons \& Michael Weber, eds, The Ethics of Self-Defense (Oxford University Press, 2016) 1. 
Secondly, I consider only the justifiability of the immigration law of constitutional democracies. To be clear, in referring to constitutional democracies, I do not mean to include all states conventionally recognized as, or that describe themselves as, liberal or constitutional democracies. Rather, I am referring to states that are properly judged to be constitutional democracies: at a minimum, such a state must equally protect all its citizens' basic rights, including their rights to political participation, and must provide all citizens with sufficient resources to meaningfully exercise these rights. I focus on constitutional democracies because, although migration to authoritarian or otherwise illiberal states is an important phenomenon empirically, constitutional democratic receiving states have a special theoretical significance within the broadly liberal framework which I presuppose.

My questions are therefore:

1. When and why are individual citizens of a constitutional democracy $D$ morally justified in nonviolently breaching the secondary immigration law of $D$ ?

2. When and why are would-be migrants to a constitutional democracy $D$ morally justified in nonviolently breaching the primary immigration law of $D$ ?

In speaking of morally justified instances of mere noncompliance, I mean to distinguish justification from permission. An act is morally permitted if it does not violate any conclusive moral duties. An act is morally justified if it is not only morally permitted but, in addition, there are sufficient positive reasons to do it. Morally justified actions so understood include, but are not limited to, morally required actions. ${ }^{7}$

As I indicated earlier, such questions concerning the political ethics of immigration have so far received scant attention in the philosophical literature. A pair of recent articles by Javier Hidalgo offers the most sustained treatment of the justifiability of noncompliance with primary and secondary immigration law known to me. ${ }^{8}$ With respect to the first of my questions, Hidalgo claims that it is morally justified for an individual citizen of a receiving state to violate particular secondary immigration laws, when and because those laws are unjust. ${ }^{9}$ With

7. See Jeff McMahan, Killing in War (Oxford University Press, 2009) at 43; Zofia Stemplowska \& Adam Swift, "Dethroning Democratic Legitimacy" in David Sobel, Peter Vallentyne \& Steven Wall, eds, Oxford Studies in Political Philosophy, vol 4 (Oxford University Press, 2018) 3 at 4 n 1 [Stemplowska \& Swift, "Dethroning"].

8. In addition to Hidalgo's account, there are other arguments that indirectly address the justifiability of noncompliance with immigration law by examining whether immigration law has legitimate authority. Notable examples include Christopher Heath Wellman \& Phillip Cole, Debating the Ethics of Immigration (Oxford University Press, 2011) at ch 1; Colin Grey, Justice and Authority in Immigration Law (Hart, 2015) at chs 1, 3-5; Margaret Moore, A Political Theory of Territory (Oxford University Press, 2015) at ch 9; David Miller, Strangers in Our Midst (Harvard University Press, 2016) at ch 4.

9. Javier Hidalgo, "The Duty to Disobey Immigration Law" (2016) 3:2 Moral Philosophy \& Politics 165 [Hidalgo, "Duty to Disobey"]. Hidalgo specifically claims that citizens are morally required to disobey unjust secondary immigration laws. This is consistent with my formulation that, on his view, disobedience is justified, since all morally required acts are also morally justified. 
respect to the second of my questions, Hidalgo claims that it is morally justified for a would-be migrant to violate particular primary immigration laws, when and because those laws are unjust. ${ }^{10}$

At the core of Hidalgo's account, then, is the claim that the injustice of a particular primary or secondary immigration law is sufficient to justify mere noncompliance. I believe, however, that this justice-focused standard is mistaken, since if immigration law has legitimate authority, then noncompliance with some unjust immigration laws may be impermissible. In this article, I will explain why Hidalgo's proposed justice-focused account should be rejected, and will develop a contrasting legitimacy-focused account of the justifiability of noncompliance with the immigration law of a constitutional democracy. ${ }^{11}$ I will also suggest that a more complete account of justified mere noncompliance with secondary immigration law must go beyond Hidalgo's exclusive focus on private, personal acts of disobedience to consider justified cases of public civil disobedience.

I propose to proceed as follows. In Section 2, I will consider would-be migrants' mere noncompliance with the primary immigration law of a constitutional democratic receiving state, arguing that they are morally justified in nonviolently breaching particular primary immigration laws of such states only if the laws in question lack legitimate authority. I will then briefly offer a qualified defense of the legitimate authority of constitutional democracies' regimes of primary immigration law in Section 3. I go on in Section 4 to argue that mere noncompliance by individual citizens of a constitutional democracy with particular secondary immigration laws is morally justified only if the laws in question lack legitimate authority. Section 5 will then explain how citizens' justified noncompliance with secondary immigration law can take the form not only of personal disobedience but also of civil disobedience.

\section{Resistance by migrants: mere noncompliance with primary immigration law}

The primary immigration law of a receiving state is that regime of laws that regulates the terms under which persons who are neither legal citizens nor legal permanent residents are authorized to enter and remain on its territory for the purposes of work and residence. When, and why, is mere noncompliance by would-be migrants with the specific laws and directives of a constitutional democracy's primary immigration law morally justified? According to Hidalgo, mere noncompliance is justified whenever a particular primary immigration law

10. Javier Hidalgo, "Resistance to Unjust Immigration Restrictions" (2015) 23:4 J Political Philosophy 450 [Hidalgo, "Resistance"].

11. I understand justice to assess the substantive moral merits and demerits of social and political institutions, especially in connection with whether these institutions honor various constituencies' entitlements to resources useful for human flourishing. By contrast, legitimacy assesses when political institutions are morally worthy of practical acceptance and support, even in the face of disagreement about the justice of its decisions. For similar understandings of the broad concept of legitimacy, see Pettit, On The People's Terms, supra note 2 at 136-40; Allen Buchanan, The Heart of Human Rights (Oxford University Press, 2013) at ch 5; Allen Buchanan, "Institutional Legitimacy," supra note 7 at 53. 
is unjust. His argument for this view appeals to a generally applicable principle of justified self- and other-defense. This principle makes two claims. First, if an individual faces an unjust threat of harm, then she is morally justified in taking nonviolent action to avert this threat. Second, an individual is morally justified in taking nonviolent action to avert unjust threats of harm to others. ${ }^{12}$

By preventing would-be migrants from living and working in a territory of their choosing, immigration restrictions harm them in various ways. They also harm some individuals who already reside in the receiving state. When primary immigration laws restricting immigration are unjust, their application and enforcement thus amounts to an unjust threat of harm to would-be migrants and/ or existing members of the receiving state. In nonviolently breaching unjust primary immigration laws, Hidalgo contends, would-be migrants avert (or contribute to averting) the unjust threats of harm these laws pose. ${ }^{13}$ By the principle of self- and other-defense, these acts of mere noncompliance are morally justified. As I understand his view, Hidalgo thus endorses what I call the

Mere Injustice Principle ${ }_{P L}$ : Would-be migrants to a constitutional democracy $D$ are morally justified in nonviolently breaching a particular primary immigration law $L_{P}$ enacted and applied by $D$ according to its established procedures if $L_{P}$ is unjust.

For him, the injustice of a primary immigration law is sufficient for mere noncompliance by would-be migrants to be justified.

However, it is doubtful that justified self- and other-defense extends as far as Hidalgo's argument supposes. Certainly, we are morally justified in using at least nonviolent means to defend ourselves and others against imminent threats of harm that violate what might be called "natural prohibitions on the use of force." 14 To put this in Lockean terms, it is morally justified to enforce the law of nature, understood as basic and uncontroversial moral principles that forbid threats to others' self-preservation. As Locke argued, when in the state of nature, individuals are justified in enforcing the law of nature themselves. Within the context of a political society, if the government violates rather than upholds the law of nature, individuals are justified in enforcing the law of nature against the government by various acts of resistance. ${ }^{15}$ But, particularly in this latter context and other contexts where political institutions are well established, it is far less clear that individuals are justified in acting to shield themselves or others from unjust threats in cases where life and limb are not at stake.

12. Hidalgo, "Resistance," supra note 10 at 455, 458. While Hidalgo uses the terms "unjust" and "unjustified" interchangeably in referring to threats of harm, I will use the term "unjust" throughout.

13. Ibid at 456-58. In articulating his view, Hidalgo focuses for illustrative purposes on immigration restrictions that are unjust in virtue of denying admission to would-be migrants who have no prospect of obtaining adequate protection for their human rights without migrating. Nevertheless, he insists that his argument "applies to any unjust immigration restrictions." Ibid at $454 \mathrm{n} 16$ [emphasis added].

14. Niko Kolodny, "Political Rule and Its Discontents" in David Sobel, Peter Vallentyne \& Steven Wall, eds, Oxford Studies in Political Philosophy, vol 2 (Oxford University Press, 2016) at 51.

15. John Locke, Two Treatises of Government, edited by P Laslett (Cambridge University Press, 1988 ) at 2.7-8, 2.168, 2.241-2. 
Indeed, the idea that acts of (even nonviolent) self- and other-defense are justified in response to every unjust threat is incompatible with accepting that at least some institutions have legitimate authority. For an institution to have legitimate authority over certain agents is for its rules to have a certain moral standing vis-à-vis those agents. This moral standing has two crucial aspects. First, the rules of such an institution are binding in the sense that they give the agents they address moral reasons to comply that normally or presumptively outweigh conflicting reasons, including moral reasons to shield themselves and/ or others from unjust threats. Second, the binding force of these rules is contentindependent. They do not bind in virtue of the merits of the actions that they require of their subjects, such as the fact that these actions promote justice. Rather, they bind in virtue of their source or provenance in the institution's relevant rule-making procedures. ${ }^{16}$ Thus, if a political institution has legitimate authority, then its subjects have a presumptive moral duty to comply with its rules regardless of whether compliance with those rules would expose them or others to unjust threats. As such, even nonviolent defensive breaches of unjust laws or rules are not always justifiable.

Focusing on the case of primary immigration law, the possibility that a constitutional democracy's regime of primary immigration law has legitimate authority casts doubt on the central contention of the Mere Injustice Principle ${ }_{\mathrm{PIL}}$, namely that the injustice of a primary immigration law is sufficient to make mere noncompliance by would-be migrants morally justified. Suppose that a receiving state's procedures for enacting and applying primary immigration law satisfy the relevant conditions for (the outcomes of) such procedures to have legitimate authority over would-be migrants. We should then judge that state's regime of primary immigration law as a whole, which is the outcome of the procedures in question, to have legitimate authority. Potential migrants would be under a presumptive, content-independent moral duty to comply with the various laws that together comprise that regime.

The duty to comply with a regime of primary immigration law that has legitimate authority is presumptive in the sense that, when a given law within that regime is tainted by a legitimacy-defeating condition, there is no conclusive duty to comply with that particular law. Since I unfortunately lack the space here to provide an exhaustive list of legitimacy-defeating conditions, I will simply draw attention to perhaps most significant example. Following what Zofia Stemplowska and Adam Swift have aptly called the "conventional view," I take it that there is no conclusive duty to comply with gravely or egregiously unjust laws-laws whose injustice exceeds a certain threshold of

16. On how authoritative directives give their addressees binding (or peremptory) and contentindependent moral reasons, see HLA Hart, "Commands and Authoritative Legal Reasons" in Essays on Bentham (Clarendon Press, 1982) at 243, 253-56; Joseph Raz, The Morality of Freedom (Clarendon Press, 1986) at 35-37; Scott Shapiro, "Authority" in Jules L Coleman, Kenneth Einar Himma \& Scott J Shapiro, eds, Oxford Handbook of Jurisprudence and Philosophy of Law (Oxford University Press, 2004) at 389; Thomas Christiano, The Constitution of Equality (Oxford University Press, 2008) at 244. 
seriousness-whatever the procedural source of these laws in question. ${ }^{17}$ In particular, would-be migrants have no conclusive moral duty to comply with egregiously unjust primary immigration laws, even when the laws in question are part of a regime of primary immigration law that, in virtue of its provenance, generally has legitimate authority. Absent egregious injustice or other legitimacy-defeating conditions, however, would-be migrants to a state whose regime of primary immigration law has legitimate authority "should refrain from violating [its primary] immigration laws, even if these laws are unjust to some degree," as Hidalgo himself acknowledges. ${ }^{18}$

Bearing in mind the relevance of the legitimate authority of a receiving state's primary immigration law to justified noncompliance with that law, I propose the

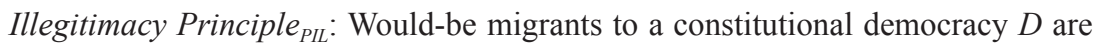
morally justified in nonviolently breaching a particular primary immigration law $L_{P}$ enacted and applied by $D$ according to its established procedures only if either (1) $D$ 's regime of primary immigration law lacks legitimate authority altogether, or (2) $D$ 's regime of primary immigration law as a whole presumptively has legitimate authority, but for $L_{P}$ in particular that presumptive legitimacy is defeated.

Note that whereas the Mere Injustice Principle ${ }_{\mathrm{PIL}}$ states a sufficient condition for justified mere noncompliance, the Illegitimacy Principle ${ }_{\mathrm{PIL}}$ simply states the conditions necessary for mere noncompliance to be justified. Whether an individual would-be migrant would be justified in nonviolently breaching a primary immigration law will also depend on whether, in the circumstances, she has sufficient positive reasons to so act. Much will therefore depend on the specific context.

Nonetheless, I take it that when the necessary conditions for justified mere

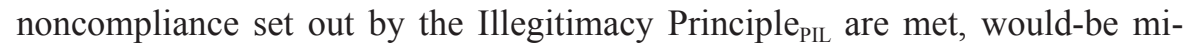
grants will often also have strong positive moral reasons to disobey. As I will argue in the next section, constitutional democracies' regimes of primary immigration law normally have legitimate authority, and hence noncompliance by would-be migrants is only permissible in cases where a particular law's legitimacy is defeated. Since a central legitimacy-defeating condition is egregious injustice, illegitimate primary immigration laws are in many instances egregiously unjust laws. Would-be migrants will have strong moral reasons-not least reasons of self- and other-defense - to disobey such laws.

As I previously pointed out, Hidalgo is aware that the possibility that a receiving state's regime of primary immigration law has legitimate authority may make the injustice of the particular laws insufficient to justify noncompliance with those laws. Nevertheless, he claims, there is no difference in the practical implications of his justice-focused Mere Injustice Principle ${ }_{\mathrm{PIL}}$ and the legitimacy-focused

17. Stemplowska \& Swift, "Dethroning," supra note 7 at 5-7. While Stemplowska and Swift themselves reject the "conventional view," it is widely accepted. See, for example, John Rawls, Political Liberalism (Columbia University Press, 1996) at 427-28; Christiano, The Constitution of Equality, supra note 16 at ch 7; Daniel Viehoff, "Democratic Equality and Political Authority" (2014) 42 Philosophy \& Public Affairs 337; NP Adams, "In Defense of Content-Independence" (2017) 23:3 Legal Theory 143 at 150.

18. Hidalgo, "Resistance," supra note 10 at 459-60. 
Illegitimacy Principle $\mathrm{PIL}_{\mathrm{PI}}$, since (even) constitutional democracies' regimes of primary immigration law lack legitimate authority over would-be migrants. The strategy he pursues is to survey several standard accounts of the conditions for a state to have legitimate authority over its members, and to argue that these accounts do not vindicate the legitimate authority of a constitutional democracy's primary immigration law. ${ }^{19}$

However, it should be no surprise that accounts of the legitimate authority of a state's domestic law - that is, laws applying to a state's existing members - do not offer the theoretical resources to explain how primary immigration law can have legitimate authority. Unlike a state's domestic law, its primary immigration law applies to persons who are not already its members. Theories of the legitimate authority of domestic law typically appeal to some morally significant feature of shared membership in a state, such as democratic co-authorship of the laws, common participation in a cooperative scheme, or standing in a valuable relationship that generates associative obligations. As such, they are unlikely to be helpful in establishing the legitimacy of primary immigration law.

Indeed, Hidalgo himself concedes this, noting that because the theories of legitimate authority and political obligation he surveys are concerned to show why the current citizens of a state are morally required to comply with their state's domestic law, it is "unsurprising on reflection" that such theories have limited relevance for assessing the legitimacy of primary immigration law. ${ }^{20}$ A more promising approach would be to examine instead theories of states' international legitimacy, and to ask whether such theories can be extended to the case of primary immigration law. It is this approach that I will follow in the next section, where I argue that constitutional democracies' regimes of primary immigration law normally have legitimate authority in virtue of those states' international legitimacy.

\section{International legitimacy and primary immigration law's legitimate authority}

Familiar judgments about the legitimate authority of a state's domestic law are judgments about what might be called first-order legitimacy: this kind of legitimacy concerns an institution's moral standing vis-à-vis those directly subject to its political rule, that is, those whose conduct the institution's rules seek to govern in the first instance. By contrast, second-order legitimacy judgments relate to an institution's moral standing vis-à-vis third parties who are not directly subject to its rule, but who are in a position to affect - to offer various degrees of practical support for, or conversely to offer practical resistance to - that relation of rule between the institution and its claimed subjects. A state's international legitimacy is a kind of second-order legitimacy: an internationally legitimate state has a certain moral standing vis-à-vis the rest of international society, namely

19. Ibid at $460-46$.

20. Ibid at 466 . 
other states and their individual members, in respect of its efforts to govern the resident population of its territory. ${ }^{21}$

Specifically, what it is for a state to have international legitimacy is, inter alia, for it to enjoy a right to political independence. This right protects the rightholder state's capacity to independently formulate and implement laws and policies in central and morally acceptable domains of domestic policymaking. In other words, the right protects the capacity of the state's members to independently choose which morally permissible public policy goals they will collectively pursue, and using what means. The correlative duty falls on international society, that is to say, other states and their members, requiring them to refrain from interfering in the rightholder state's domestic governance. It is thus also often described as "a right to noninterference in internal affairs." 22

This duty of noninterference is content-independent in the sense that it presumptively forbids interference by international society regardless of the moral merits or demerits of the specific domestic policies an internationally legitimate state chooses to implement, at least to the extent that these policies are not undertaken in furtherance of clearly impermissible goals. Moreover, it is a binding moral duty that normally outweighs competing considerations; it does not simply reflect the tendency in practice for interference to be counterproductive or to cause international instability. These aspects of the duty of noninterference are captured in the helpful formulation that internationally legitimate states are owed "principled toleration" by international society for their domestic political decisions. ${ }^{23}$ This formulation brings out that the members of international society ought, for moral rather than simply prudential or strategic reasons, to avoid interfering even with those domestic laws and policies of internationally legitimate states that they object to.

An internationally legitimate state's right to political independence and international society's correlative duty of noninterference or principled toleration has important implications for the authority of such a state's primary immigration law over would-be migrants. Immigration, especially on a large scale, will typically have a substantial impact on various aspects of the receiving state's economy and society that the state's domestic policies might reasonably seek to regulate. For example, the rate of immigration and the skill composition of the entering pool of immigrants tends to affect outcomes in the domestic labor market, the rate of labor productivity, levels of expenditure on social services and the welfare state, levels of government revenue, the size of aggregate economic output, and other outcomes of concern to domestic economic and fiscal

21. To be clear, I do not claim that the legitimate authority of primary immigration law is a form of second-order legitimacy, only that international legitimacy is.

22. Allen Buchanan, Justice, Legitimacy, and Self-Determination (Oxford University Press, 2004) at 264. See also Andrew Altman \& Christopher Heath Wellman, A Liberal Theory of International Justice (Oxford University Press, 2009) at 4.

23. Michael Blake, Justice and Foreign Policy (Oxford University Press, 2013) at 59. To be clear, although Blake holds that states are sometimes owed principled toleration by international society, he himself avoids the notion of international legitimacy because he rejects the binary character of international legitimacy judgments in favor of a more scalar approach. Ibid at 68-69. 
policy. Hence, there is a tight functional connection between, on the one hand, a state's capacity to pursue its chosen domestic policy goals and implement its preferred policies and, on the other hand, its capacity to regulate immigration to its territory. A state that lacks an effective capacity to unilaterally regulate immigration will have its ability to shape relevant economic and social outcomes within its territory according to its members' choice impaired to a significant degree.

In light of this functional connection between the capacity to regulate immigration and the capacity to govern domestically, I argue that the following specific duty is implied by the general duty of noninterference owed to internationally legitimate states: international society is to refrain from actions and policies that will significantly undermine an internationally legitimate state's capacity to independently regulate immigration to its territory without its consent. ${ }^{24}$ Since it is derived from a content-independent duty of noninterference, it too is contentindependent: it presumptively forbids international society from disrupting the regulations which an internationally legitimate state has placed on immigration to its territory, in virtue of their being the product of the state's internal political decisions, not in virtue of their substantive moral merits or demerits.

Assuming that a given state's capacity to regulate immigration would be significantly undermined if there was widespread noncompliance by would-be migrants with its regime of primary immigration law, I argue that other states and their members - including and especially would-be migrants - are collectively required to prevent this level of noncompliance if the state satisfies the criteria for international legitimacy. Each individual would-be migrant to that state is then required to do her fair share in discharging this collective duty. This fair share consists in each would-be migrant's compliance with the regime of primary immigration law of the state in question. Hence, would-be migrants to a state that has international legitimacy have a presumptive, content-independent moral duty to comply with the primary immigration laws that regulate admission to and residence in that state's territory. We can say, equivalently, that when a state has international legitimacy, then its regime of primary immigration law has legitimate authority over would-be migrants.

If I am right that, when a state is internationally legitimate and hence entitled to political independence, its regime of primary immigration law has legitimate authority, then whether constitutional democracies' regimes of primary immigration law have legitimate authority depends on whether constitutional democracies satisfy the conditions for international legitimacy. Lacking the space here to defend any particular account of the criteria for states to be legitimate vis-à-vis international society, I will simply appeal to the wide consensus that at least those states properly judged to be constitutional democracies enjoy international legitimacy, or in any case that aspect of international legitimacy that concerns us here, namely the right to political independence.

24. A state may consent to have its capacity to independently regulate immigration curtailed by, for example, entering into a bilateral or multilateral agreement with other states to reciprocally allow freedom of movement. 
On one view, all states that recognize and protect basic human rights domestically are entitled to political independence..$^{25}$ On another view, the conditions for international legitimacy are that a state adequately protects the human rights of its members and respects the human rights of nonmembers. ${ }^{26} \mathrm{~A}$ third view claims that a state is internationally legitimate if it adequately protects human rights internally, has at least a minimally democratic political system, respects human rights externally, and did not (recently) usurp the jurisdiction of another legitimate state. ${ }^{27}$ Finally, some philosophers claim that only liberal states - those whose institutions secure for all their members equal protection for the basic civil and political rights essential for individual autonomy - should be recognized as internationally legitimate. ${ }^{28}$

These accounts all suggest that (at least) constitutional democracies normally satisfy the conditions to enjoy a right to political independence. Any political society that satisfies the criteria to be properly judged a constitutional democracy will equally and adequately protect its members' human rights. Constitutional democracies also tend to respect human rights in their dealings with other states, and to avoid aggressive war against legitimate states. ${ }^{29}$ On the assumption that this consensus about the international standing of constitutional democracies is sound, my argument in this section implies that a constitutional democratic state's regime of primary immigration law normally has legitimate authority over would-be migrants. If so, then the Illegitimacy Principle ${ }_{\mathrm{PIL}}$ has substantially different practical implications than the Mere Injustice Principle PIL $_{\text {. }}$

Anticipating an argument of this kind, Hidalgo offers the following objection. Even if primary immigration law has legitimate authority, this legitimacy is defeated in the case of any particular law that restricts immigration in such a way as to directly threaten or foreseeably enable unjust harm to would-be migrants. The reason is that states "lack rights against external interference when they pose [unjust] threats to outsiders." 30 Whenever a state's laws threaten or foreseeably enable unjust harm to outsiders, these outsiders' presumptive duty to refrain from interfering in that state's domestic governance is defeated, and thus their derivative duty to comply with its primary immigration law is also defeated.

Note that, even if successful, this reply would not show that injustice to insiders is a defeating condition on the legitimacy of primary immigration law. Hence, it does not show that the Illegitimacy Principle PIL $_{\text {always has the same }}$ practical implications as the Mere Injustice Principle ${ }_{\mathrm{PIL}}$. Nevertheless, the legitimate authority of a constitutional democracy's primary immigration law would be severely circumscribed if it is indeed defeated whenever a particular law poses a threat of unjust harm to would-be migrants or to nonmembers more generally.

25. John Rawls, The Law of Peoples (Harvard University Press, 1999) at 59-62, 78-81.

26. Altman \&Wellman, A Liberal Theory of International Justice, supra note 22 at 3-4.

27. Buchanan, Justice, Legitimacy, and Self-Determination, supra note 22 at ch 6.

28. Kok-Chor Tan, Toleration, Diversity, and Global Justice (Pennsylvania State University Press, 2000) at ch 4; Blake, Justice and Foreign Policy, supra note 23 at ch 3.

29. Michael Doyle, "Kant, Liberal Legacies, and Foreign Affairs" (1983) 12:3 Philosophy \& Public Affairs 203.

30. Hidalgo, "Resistance," supra note 10 at 467. 
It is thus worth interrogating whether an internationally legitimate state's right to political independence covers only political decisions that wrong its own members, but not decisions that wrong outsiders.

To be sure, a state's right to independence does not extend to political decisions that directly violate the human rights of nonmembers, or even to decisions that shirk its required share of the international responsibility to act in defense of all individuals' human rights when their own states are unable or unwilling to extend adequate protection. The legitimate authority of a constitutional democracy's regime of primary immigration law is thus defeated in the case of specific laws that directly violate or unjustly fail to defend the human rights of nonmembers such as would-be migrants. To put this another way, such laws are tainted by egregious, legitimacy-defeating injustice.

For example, the legitimacy of primary immigration laws that restrict the admission of refugees is defeated. Refugees, considered as a morally distinctive category of potential migrants, are individuals who currently lack adequate protection for their human rights - including socioeconomic human rights - in their current state of residence and have no reasonable prospect of obtaining a domestic remedy for this deficiency in protection. They therefore need residence in some other state from which they can obtain surrogate protection for their human rights. ${ }^{31}$ Indeed, we could say that they have a (derivative) human right to obtain surrogate protection. At least under prevailing circumstances, where there is no effective international refugee responsibility-sharing scheme, a constitutional democracy that has the capacity to offer such surrogate protection will be violating this derivative human right if it denies refugees admission.

But we can also imagine other political decisions that an internationally legitimate state might make in pursuit of some permissible domestic policy goal that, while unjust to outsiders to some degree, do not violate human rights. It seems that such decisions are protected by the state's right to political independence. Consider, as an example, an internationally legitimate state that enacts a customs law that, due to the effects of the schedule of tariffs it imposes, offends against some transnational principle of fairness in trade but does not violate human rights. It does not seem that this injustice against outsiders would permit nonmembers to smuggle goods into the state's territory to evade the customs law in question.

This case suggests that the international legitimacy of a state is not defeated whenever its political decisions threaten to unjustly harm nonmembers. Only when a certain threshold of egregious injustice is reached will a state's international legitimacy be defeated. This further suggests that injustice to would-be migrants or other outsiders is not always a defeating condition on the legitimate authority of primary immigration law. Although the primary immigration laws

31. For the idea that what distinguishes refugees is their need for surrogate or substitute protection, see Canada (Attorney General) v Ward [1993] 2 SCR 689; James Hathaway \& Michelle Foster, The Law of Refugee Status, 2nd ed (Cambridge University Press, 2014) at 184-85, 287-94. For similar conceptions of refugeehood, see Matthew Gibney, The Ethics and Politics of Asylum (Cambridge University Press, 2004) at 7-9; David Owen, "In Loco Civitatis" in Sarah Fine \& Lea Ypi, eds, Migration in Political Theory (Oxford University Press, 2016) at 276-80. 
of a constitutional democracy that violate or fail to properly defend the human rights of would-be migrants are illegitimate, this is not always true of other unjust immigration laws of such a state.

At this point, Hidalgo might insist in response that there is a human right to immigrate according to one's choice: freedom of immigration is a human right. This line of response is more radical than the previous one, since its implication is that almost all primary immigration laws that restrict immigration are egregiously unjust and hence illegitimate. In any case, if successful, this argument would again vitiate the practical difference between the Mere Injustice Principle $\mathrm{PIL}_{\mathrm{PL}}$ and the Illegitimacy Principle $_{\text {PIL }}$. Indeed, it would cast serious doubt on the idea that any regime of primary immigration law — whatever its procedural provenance - could have legitimate authority, since presumably any legal regime that systematically violates human rights would lack legitimate authority.

Proponents of freedom of immigration as a human right typically emphasize the value to individuals generally of being able to immigrate according to their choice: the absence of restrictions on their migration choices would greatly facilitate individuals' access to valuable options outside their current state of residence, thereby promoting their fundamental interests in personal and even political autonomy. They claim that because freedom of immigration serves fundamental individual interests in autonomy, it should receive protection as a human right, just as freedom of internal movement receives such protection. ${ }^{32}$

Individuals certainly have important and valid interests in being free to immigrate according to their choice. Nevertheless, a successful argument for a human right to freedom of immigration cannot appeal only to the value for individuals of enjoying this kind of freedom. To vindicate that freedom as a human right, we would also need to show that, for any given individual, the members of political societies other than her own have the same kind of duty to serve her migrationrelated interests as do the members of her own political society.

If what individuals can rightfully claim from others and what they owe to others does not vary fundamentally based on which states they are members of, then this is easy to show. But if we instead hold, following internationalist views of global justice, that shared membership in a state is a morally significant social and political relation that grounds duties of justice that co-citizens specially owe each other, then there is a basis to resist the abovementioned assignment of duties. ${ }^{33}$ While the members of each state owe it to each other to secure one another's fundamental autonomy interests through the establishment of a common scheme of equal basic rights, they have no comparable duty to promote the parallel interests of the members of other states. Hence, although freedom

32. Joseph Carens, The Ethics of Immigration (Oxford University Press, 2013) at ch 11; see Kieran Oberman, "Immigration as a Human Right", supra note 31.

33. Unfortunately, I lack the space here to defend internationalism as an account of global justice. Prominent defenses are offered in David Miller, National Responsibility and Global Justice (Oxford University Press, 2007); Andrea Sangiovanni, "Global Justice, Reciprocity, and the State" (2007) 35:1 Philosophy \& Public Affairs 3 at 6-7; Altman \& Wellman, A Liberal Theory of International Justice, supra note 22 at ch 6; Matthias Risse, On Global Justice (Princeton University Press, 2012) at 48-53; Blake, Justice and Foreign Policy, supra note 23 at chs 1 and 4. 
of immigration would serve the fundamental autonomy interests of (would-be) migrants, there is no human right to that freedom. ${ }^{34}$

To be clear, while I claim that there is no human right to immigrate according to one's choice, I fully accept that there are human rights-based requirements on receiving states to authorize immigration in particular circumstances and for specific protected reasons. Two illustrative examples concern refugees and family migration. As I noted earlier, refugees have a derivative human right to immigrate for the purpose of accessing surrogate human rights protection. Family migration provides another example. It has been plausibly argued that undue restrictions on the entry and settlement of noncitizens who are joined in certain family or other close, nonfungible personal relationships with existing citizens of the receiving state in question violate human rights - if not the human rights of the would-be migrants themselves then of the existing citizens who share the relevant relationships with them. These arguments appeal to a human right to (the social bases) of those relationships that have a special connection to individual autonomy, a human right that is violated by immigration restrictions that unduly burden the maintenance of such relationships among persons who are separated by such restrictions. ${ }^{35}$

I have sketched a conditional argument for the view that there is no human right to freedom of immigration, even if there are human rights-based entitlements to immigrate in particular circumstances - conditional, that is, on the truth of some internationalist conception of global justice. Supposing that this argument is accepted, then primary immigration laws are not, in general, illegitimate because egregiously unjust. There is some range of laws regulating would-be migrants' admission to a constitutional democracy that they are morally required to comply with even if those laws are to some degree unjust: the Illegitimacy Principle does not, at a practical level, collapse into the Mere Injustice Principle PIL $_{\text {. }}$

Before turning my attention to secondary immigration law, I want to consider a further potential worry about my argument for the legitimate authority of a constitutional democracy's regime of primary immigration law. My argument is, or may appear to be, similar in some ways to a number of other accounts defending - in the more familiar formulation within the extant philosophical literature - a (legitimate) state's right to control immigration by appeal to a right to self-determination held by political or national communities. Some of these arguments have been subject to serious criticism. I want to suggest how my own view is able to escape these criticisms.

Firstly, my argument does not depend on the controversial idea that the population or citizenry of each state has a distinctive culture or national identity, and that the preservation of this distinctive culture or identity grounds a collective

34. I develop this argument at greater length in Caleb Yong, "Immigration Rights and the Justification of Immigration Restrictions" (2017) 48:4 J Social Philosophy 461. For a similar argument, see Adam Hosein, "Immigration and Freedom of Movement" (2013) 6:1 Ethics and Global Politics 25.

35. See Matthew Lister, "Immigration, Association, and the Family" (2010) 29 Law \& Phil 717; Caleb Yong, "Caring Relationships and Family Migration Schemes" in A Sager, ed, The Ethics and Politics of Immigration (Rowman \& Littlefield, 2016). 
right to regulate the admission of migrants into the state's territory and political membership. ${ }^{36}$ Rather, my argument traces the legitimate authority of a state's regime of primary immigration law to its right, as an internationally legitimate state, to political independence. Moreover, while some might hold that the right to political independence itself is justified because it serves to protect and preserve the distinctive culture or identity embodied within each state's existing membership, ${ }^{37}$ my argument need not rely on this view given that other-arguably more plausible - accounts of the grounds for the right to political independence are available. ${ }^{38}$

My view likewise does not depend on the argument that a constitutional democratic state has a right to control immigration because such control is necessary to protect the capacity of its existing membership to determine the composition of the state's future membership, which is in turn a central element of a state's collective self-determination. ${ }^{39}$ This argument, which understands self-determination to require what Bas van der Vossen has called "self-creation," has been criticized by him on the ground that when the ideal of self-creation is given a plausible interpretation, the regulation of immigration is normally not a precondition for it. ${ }^{40}$ To accept my account, however, one need not hold that an internationally legitimate state's control over the future composition of its membership is among the domains of policymaking that international society must not interfere with. It is enough to accept the relatively uncontroversial idea that an internationally legitimate state's right to political independence protects at least its independent political control over domestic economic and fiscal policy.

\section{Citizens' mere noncompliance with secondary immigration law}

Many individuals among the current citizenry of a receiving state, in their capacity as occupants of certain social (especially official) roles, are legally obligated to participate in implementing their state's primary immigration law. Obviously, immigration officers - that is, public officials tasked with monitoring immigration and enforcing immigration law - are legally required to engage in efforts to detect and deter unauthorized immigration, as well as to carry out immigration enforcement, for example, by deporting unauthorized migrants. In addition, employers are prohibited from knowingly hiring noncitizens who are not legally authorized to access the labor market. Police officers, university administrators,

36. Cf Michael Walzer, Spheres of Justice: a Defence of Pluralism and Equality (Basic Books, 1983 ) at ch 2; Moore, Political Theory of Territory, supra note 8 at 199-200.

37. Michael Walzer, Thinking Politically (Yale University Press, 2007) at chs 12-13.

38. See, for example, Blake, Justice and Foreign Policy, supra note 23 at 59-67; Anna Stilz, "The Value of Self-Determination", supra note 14; Sarah Song, "Why Does the State Have the Right to Control Immigration?" in Jack Knight, ed, Immigration, Emigration, and Migration: NOMOS LVII (New York University Press, 2017) 3 at 35-37.

39. See generally Walzer, Spheres of Justice, supra note 36; Wellman \& Cole, Debating the Ethics of Immigration, supra note 8 at 40-41; Miller, Strangers in our Midst, supra note 8 at 62-63; Moore, Political Theory of Territory, supra note 8 at 197.

40. Bas van der Vossen, "Immigration and Self-Determination" (2015) 14:3 Politics, Philosophy \& Economics 270 at $278-85$. 
and various providers of public services may also be required to report suspected immigration offenses to immigration officers. ${ }^{41}$

Hidalgo plausibly suggests that these directives of secondary immigration law, which he calls "interaction restrictions," are unjust insofar as they serve to implement unjust primary immigration laws. ${ }^{42}$ A simple argument for this claim is that secondary immigration law is designed to facilitate the implementation of primary immigration law, and laws designed to facilitate other unjust laws are themselves unjust. In complying with secondary immigration laws that are unjust in this way, individual citizens of the receiving state in question causally contribute to the injustice of the primary immigration laws that are thereby implemented; as such, they are complicit in injustice. Since individual citizens have a moral duty to avoid such complicity, Hidalgo argues, they are morally justified in refusing to comply with any secondary immigration law that is unjust. ${ }^{43}$ As I understand his view, he endorses what I call the

Mere Injustice Principle SIL $_{\text {: Individual citizens of a constitutional democracy } D \text { are }}$ morally justified in nonviolently breaching a particular secondary immigration law $L_{S}$ enacted and applied by $D$ according to its established procedures if $L_{S}$ is unjust.

According to this principle, the injustice of a secondary immigration law is a sufficient condition for mere noncompliance by individual citizens.

The possibility that a constitutional democracy's regime of secondary immigration law has legitimate authority undermines the Mere Injustice Principle SIL $_{\text {. }}$ Recall that what it is for a political institution to have legitimate authority is for the rules issued by its established rule-making procedures to be binding on its subjects based on the rules' procedural provenance and not on their content. Hence, if a receiving state's procedures for enacting and applying secondary immigration law satisfy the relevant conditions for (the outcomes of) such procedures to have legitimate authority over its existing citizens, then individual citizens have a presumptive, content-independent moral duty to comply with the various laws that together comprise that state's regime of secondary immigration law. To be sure, since this duty to comply with a regime of secondary immigration law that has legitimate authority is presumptive, in the case of particular laws where some legitimacy-defeating condition is present, citizens lack a conclusive duty to comply. As we have seen in Section 2, a major such condition is the presence of especially grave injustice: if a particular secondary immigration law is egregiously unjust, then there is no conclusive duty to comply, whatever the procedural provenance of that law might be.

Nevertheless, if a state's regime of secondary immigration law has legitimate authority, then when legitimacy-defeating conditions are absent, its citizens are morally required to comply even with particular laws that are unjust to some degree - a duty that outweighs the competing moral reasons they have to avoid being complicit in injustice. Contrary to what the Mere Injustice Principle SIL $_{\text {holds, }}$

41. Hidalgo, "Duty to Disobey," supra note 9 at 169-70.

42. Ibid at $170-72$.

43. Ibid at $172-75$. 
then, the injustice of a secondary immigration law may not be sufficient to justify mere noncompliance by a receiving state's existing citizens.

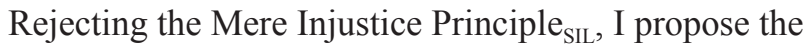

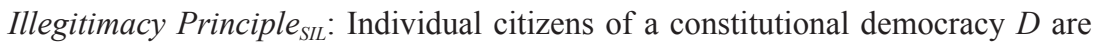
morally justified in nonviolently breaching a particular secondary immigration law $L_{S}$ enacted and applied by $D$ according to its established procedures only if either (1) $D$ 's regime of secondary immigration law lacks legitimate authority altogether, or (2) $D$ 's regime of secondary immigration law as a whole presumptively has legitimate authority, but for $L_{S}$ in particular that legitimacy is defeated.

As with the earlier Illegitimacy Principle ${ }_{\mathrm{PIL}}$, it is worth noting that the Illegitimacy Principle $_{\text {SIL }}$ states a necessary - not sufficient - condition for mere noncompliance to be morally justified. To determine if mere noncompliance with an illegitimate secondary immigration law is justified in a given case, we must make further assessments regarding whether there are sufficient positive reasons to nonviolently breach that law in the relevant circumstances. One type of circumstance in which there will be sufficient moral reasons for mere noncompliance, which I will further discuss below, is when a secondary immigration law is egregiously unjust.

Hidalgo is aware of the challenge that the idea of legitimate authority poses to his account. His strategy in responding to this challenge is to argue that (even) constitutional democracies' regimes of secondary immigration law lack legitimate authority, and hence mere noncompliance with their secondary immigration laws is in fact justified whenever such laws are unjust. ${ }^{44}$ This line of response attempts to show that, even if the appropriate standard by which to judge the justifiability of mere noncompliance must take the legitimacy or otherwise of secondary immigration law into account, the Illegitimacy Principle SIL $_{\text {collapses }}$ in practical terms into the Mere Injustice Principle ${ }_{\mathrm{SIL}}$.

In reply, I will indicate why a constitutional democracy's regime of secondary immigration law does in fact have legitimate authority. I begin with the widely held view that the domestic law of a constitutional democracy has legitimate authority over its own citizens, at least when the legislative process is guided by appropriate reasons. ${ }^{45}$ I stress again that, in speaking of constitutional democracies, I am referring to those states that in fact satisfy the criteria to be properly judged as a political regime of this type. In such a genuine constitutional democracy, at least when citizens and legislators exercise their political rights guided by reasons of social and global justice and the common good of their society, I take it that the domestic law enacted by the state's established procedures has legitimate authority. One type of domestic law is secondary immigration law:

44. Ibid at 179-83.

45. See for example John Rawls, "The Idea of Public Reason Revisited" (1997) 64:3 U Chicago L Rev 765; Jeremy Waldron, Law and Disagreement (Oxford University Press, 1999); David Estlund, Democratic Authority (Princeton University Press, 2008); Christiano, Constitution of Equality, supra note 16 at chs 6-7; Niko Kolodny, "Rule Over None II: Social Equality and the Justification of Democracy" (2014) 42:4 Philosophy \& Public Affairs 287; Viehoff, "Democratic Equality and Political Authority", supra note 17. 
the agents whose conduct this kind of immigration law seeks to regulate are not would-be migrants but current citizens. Hence, the secondary immigration law of a constitutional democratic receiving state has legitimate authority over that state's current citizens.

As a rejoinder to this appeal to the legitimate authority of a constitutional democracy's domestic legislation, Hidalgo argues that any regime of law that systematically violates or facilitates the violation of human rights cannot have legitimate authority. ${ }^{46} \mathrm{He}$ further urges that, because freedom of immigration is a human right, those secondary immigration laws that serve to implement immigration restrictions systematically facilitate the violation of human rights. As such, even if the domestic legislation of a constitutional democracy generally enjoys legitimate authority, its regime of secondary immigration law constitutes an important exception. ${ }^{47}$

I agree that any regime of law that systematically violates, or contributes to the violation of, human rights lacks legitimate authority. But as I argued in Section 3 , we should reject the view that there is a human right to immigrate according to one's choice, at least if we assume an internationalist conception of global justice. If freedom of immigration is not a human right, then a constitutional democracy's regime of secondary immigration law is not so systematically marked by egregious injustice that, by contrast with other parts of its domestic law, it lacks legitimate authority. As such, not only does the Illegitimacy Principle SIL $_{\text {rather }}$

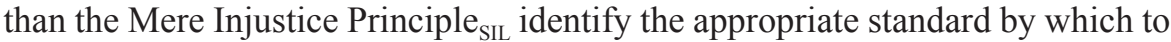
judge the justifiability of mere noncompliance with secondary immigration law, but the two principles also have substantively different practical implications.

I want to emphasize, however, that when a constitutional democracy enacts primary immigration laws that violate human rights, for example by unduly restricting the admission of refugees and family migrants, then those of its secondary immigration laws that serve to implement these immigration restrictions unjustly facilitate human rights violations. Such laws are egregiously unjust and hence illegitimate; as such, individual citizens have no conclusive duty to comply with them. Moreover, given individual citizens' moral duty to avoid complicity in injustice, they will also have strong positive reasons to disobey secondary immigration laws of this kind. At least in those cases where a particular secondary immigration law is egregiously unjust, then, mere noncompliance by individual citizens is justified.

A potential objection to this last claim is that noncompliance by those citizens who are public officials is impermissible even in the case of egregiously unjust laws, in virtue of those citizens' role obligations as public officials. On this view, those citizens of a constitutional democracy who occupy official roles have a role-relative, content-independent moral duty to fulfil the legal obligations that

46. The claim here is not that there is no conclusive duty to comply with particular laws that violate or facilitate the violation of human rights, but the more general claim that any institution or legal regime that systematically violates or facilitates the violation of human rights must lack legitimate authority altogether.

47. See Hidalgo, "Duty to Disobey", supra note 9 at 166-69, 179-80, 182-83. 
apply to them in their official capacity. A public official should not normally breach her role-specific legal obligations even when these conflict with her (correct) ethical, moral, and political convictions ${ }^{48}$ If so, then mere noncompliance by public officials with the secondary immigration laws that apply to them in their official capacity is unjustified, even when these officials correctly judge the laws in question to be unjust.

In my view, it is democratic legitimacy that best explains public officials' putative content-independent moral duty to fulfil their role-specific legal obligations. ${ }^{49}$ When officials carry out the requirements of their various respective roles, the laws legitimately enacted by their state's constitutional democratic procedures are thereby implemented. But if officials discharged their role-specific legal obligations only when these legal directives are fully compatible with their individual moral beliefs, then given the inevitability of moral disagreement, stable arrangements for the implementation of legitimate laws would be impossible. It is in light of these considerations that officials have a content-independent moral duty to fulfil their role-specific legal obligations. Given this grounding, the scope of public officials' role-relative moral duties do not extend to illegitimate laws. With one important exception that I will discuss in the next section, therefore, the conditions for justified mere noncompliance with secondary immigration law do not significantly differ between public officials and ordinary citizens.

\section{Going beyond personal disobedience}

I have suggested that, at least in one sense, Hidalgo's account of the justifiability of mere noncompliance with secondary immigration law goes too far. He holds that mere noncompliance by the individual citizens of a constitutional democracy with their state's secondary immigration laws is morally justified whenever these laws are unjust. By contrast, I have argued that, because a constitutional democracy's regime of secondary immigration law has legitimate authority over its existing citizens, individual citizens of a constitutional democracy are only justified in violating one of their state's secondary immigration laws when some legitimacy-defeating condition, such as egregious injustice, is present.

Yet, in another sense, Hidalgo's account does not go far enough. His argument for the justifiability of noncompliance by citizens focuses solely on one ground for refusing compliance, namely the moral imperative to avoid complicity in injustice. I hope to show in this section why this narrow focus on avoiding complicity as the ground for justified noncompliance risks conveying an overly privatized understanding of justified resistance to injustice in immigration law, and to draw attention to another ground for justified noncompliance that has a more civic and public character.

This further ground for noncompliance also appeals to moral reasons. Note, however, that by discussing only instances of principled - that is, morally

\footnotetext{
48. Something like this view is expressed in Michael Quinlan, "Ethics in the Public Service" (1993) 6:4 Governance: An Int'l J Policy and Administration 538.

49. See Arthur Isak Applbaum, Ethics for Adversaries (Princeton University Press, 1999) at ch 4.
} 
motivated or conscientious - noncompliance, I do not mean to suggest that acting for the sake of principle is the only way that mere noncompliance with secondary immigration law can be justified. I leave open the possibility that, in certain circumstances, mere noncompliance for nonmoral reasons is justified when a given law is illegitimate. ${ }^{50}$ Nevertheless, because the most salient instances of noncompliance with secondary immigration law are cases of principled noncompliance, I devote particular attention to this kind of noncompliance.

When citizens of a receiving state violate their state's secondary immigration laws on the ground that their moral duty to avoid complicity in injustice requires them to do so, they engage in the type of principled noncompliance that, following Kimberley Brownlee, I call personal disobedience. ${ }^{51}$ Acts of personal disobedience are distinguished by their noncommunicative and nonpolitical nature. A personal disobedient violates a law because it commands actions that, she believes, are morally prohibited. However, she does not seek by her disobedience to publicly communicate any judgment about that law's injustice nor to make a moral appeal to her co-citizens to reform the law in question. Joseph Raz thus aptly characterizes personal disobedience as "essentially a private action." 52 The private character of personal disobedience is underlined by the fact that it can be carried out entirely covertly or surreptitiously. ${ }^{53}$

Hidalgo is certainly right to identify a receiving state's citizens' moral reasons to personally avoid complicity in institutional injustice as a potential ground of justified noncompliance with secondary immigration law. Suppose that a particular secondary immigration law of a constitutional democracy is tainted by egregious, legitimacy-defeating injustice. In such a case, individual citizens have no duty to comply with the law in question, and their duty to avoid being complicit in injustice provides sufficient reasons in favor of disobeying the law to make their mere noncompliance morally justified.

Nevertheless, there is a distinct (principled) ground for justified noncompliance that Hidalgo does not discuss: citizens may refuse to comply in an effort to promote reform of unjust secondary immigration laws. This is a distinct moral motivation for noncompliance, even if reasons to promote the reform of unjust arrangements share with reasons to avoid complicity a common foundation in the natural duty of justice. This duty requires individuals, firstly, to practically accept and support just institutions, and secondly, to oppose institutional injustices. The second requirement implies not only an imperative to avoid contributing to any institutional injustice - that is, to avoid being complicit in injustice - but also an imperative to actively "remove any injustices" by contributing to efforts

50. Many justified breaches of law take this form: they are morally justified or permissible but their motivation comes from other considerations. See Joseph Raz, The Authority of Law (Oxford University Press, 1979) at 263.

51. Kimberley Brownlee, Conscience and Conviction (Oxford University Press, 2012) at 27-29. Other terms that have been applied to principled noncompliance that is noncommunicative and nonpolitical are conscientious objection, conscientious refusal, and conscientious evasion. See Raz, Authority of Law, supra note 50 at 263-64, 276; Rawls, A Theory of Justice, supra note 1 at 368-69.

52. Raz, Authority of Law, supra note 50 at 264.

53. Brownlee, Conscience and Conviction, supra note 51 at 29. 
to reform existing institutions that are unjust. ${ }^{54}$ Breaches of law that, guided by this latter imperative, aim to promote the reform of unjust laws and policies are acts of civil disobedience. ${ }^{55}$

In contrast to personal disobedience, civil disobedience is both communicative and political. It is communicative in that civil disobedients use their breaches of law to call their co-citizens' attention to the injustice of particular aspects of their state's institutions, and to make a public moral appeal for reform. As an intervention in the public forum, civil disobedience cannot be undertaken in a wholly covert manner. While there might be sound strategic reasons for civil disobedients not to announce their intentions in advance-for example, so as not to provide the authorities with an opportunity to preemptively abort the intended breaches of law - civil disobedients must at some point publicize their breach of the law to their co-citizens. ${ }^{56}$ Civil disobedience is political since it is a form of contestation: civil disobedients break the law with the aim of persuading their co-citizens to support the reform of unjust laws and policies. ${ }^{57}$

Because Hidalgo focuses on personal disobedience to the neglect of civil disobedience in his account of individual citizens' justified noncompliance with unjust secondary immigration laws, he risks obscuring the moral significance of citizens' status as citizens - that is, as equal sharers in their state's authorization and exercise of political power, which in a constitutional democracy is ultimately "the power of free and equal citizens as a collective body." 58 The citizens of a receiving state that has adopted unjust immigration laws can do more than simply acting to limit their personal contribution to the implementation of these unjust laws. They are also in a position to intervene in democratic deliberation and decision-making by means up to and including civil disobedience, with a view to persuading their co-citizens to support the repeal and reform of the laws in question.

Indeed, some have plausibly suggested that citizens of a constitutional democracy should view civil disobedience as a "final device" that they can activate as a countermajoritarian check when legal forms of contestation have proven fruitless.$^{59}$ There is a strong case for such a final checking device on immigration laws unilaterally enacted by states. Because the procedure by which a state's immigration laws are enacted denies outsiders any formal opportunity for influence, such legislation has a worrying tendency to neglect the claims and interests

54. Rawls, A Theory of Justice, supra note 1 at 246. On the natural duty of justice, see ibid at 115 , 334. See also the "communicative principle of conscientiousness" in Brownlee, Conscience and Conviction, supra note 51 at 29.

55. This account of civil disobedience I take to be broadly compatible with both what William Scheuerman calls the "liberal model" and the "democratic model" of civil disobedience (Civil Disobedience (Polity, 2018) at chs 2-3).

56. William Scheuerman, "Recent Theories of Civil Disobedience: An Anti-Legal Turn?" (2015) 23:4 J Political Philosophy 427 at 440.

57. Rawls, A Theory of Justice, supra note 1 at 364-67; Robin Celikates, "Democratizing Civil Disobedience" (2016) 42:10 Philosophy and Social Criticism 953 at 985-86.

58. John Rawls, Justice as Fairness: A Restatement (Harvard University Press, 2001) at 40.

59. Rawls, A Theory of Justice, supra note 1 at 382-84. See also Jürgen Habermas, "Civil Disobedience: Litmus Test for the Democratic Constitutional State" (1985) 30 Berkeley Journal of Sociology 95 at 103-05. 
of would-be migrants and other noncitizens. ${ }^{60}$ Civil disobedience by individual citizens of a receiving state offers an important device to counteract these epistemic defects in the procedures by which states enact their immigration laws.

I have pointed to civil disobedience as a distinct form of principled noncompliance, and highlighted its value as an important device by which individual citizens of a constitutional democracy might oppose injustices in their state's immigration laws. When are such civilly disobedient actions justified? By the Illegitimacy Principle ${ }_{\mathrm{SIL}}$, civil disobedience-like any form of noncompliance with the secondary immigration laws of a constitutional democracy - is only justified as a response to immigration laws tainted by some legitimacy-defeating feature, such as egregious injustice. When immigration laws are egregiously unjust, citizens will additionally have strong positive moral reasons, grounded in the natural duty of justice, to use civilly disobedient acts to contest them.

Nonetheless, it is harder to morally justify civil disobedience than comparable acts of personal disobedience, since the former's public and political character risks encouraging others to "[resort] to disobedience to achieve whatever changes in law or policy they find justified," thereby potentially undermining the stability of the state's constitutional democratic system. ${ }^{61}$ The risk of destabilizing or otherwise inflicting systemic damage on democratic institutions is especially great when public officials, such as immigration officers and providers of social services, engage in civil disobedience. Civil disobedience undertaken by public officials has the potential to corrode the public's confidence that officials are committed to upholding the rule of law and to remaining appropriately politically neutral. ${ }^{62}$

I therefore suggest that citizens of a constitutional democracy should only target injustices in their state's immigration law via civil disobedience when they have already gone through legal channels of democratic contestation, without success. ${ }^{63}$ In addition, because civil disobedience is one way of discharging the nonideal imperatives of the natural duty of justice, namely to promote the reform of unjust institutions in the direction of greater justice, it should be guided by the general principles that apply to nonideal political action. Specifically, citizens should avoid acts of civil disobedience unless these are likely to be effective in persuading their co-citizens to enact more just immigration laws. If civil disobedience can be expected to provoke a backlash leading to the enactment of morally worse immigration legislation, for example, then it is unjustified. ${ }^{64}$ Beyond these

60. See Javier Hidalgo, "The Case for the International Governance of Immigration" (2016) 8:1 Int'l Theory 140 at $144-54$. Although states' independent political control over immigration to their territories is vulnerable to these epistemic biases, I doubt that the moral risks associated with these biases are serious enough to wholly undermine the legitimate authority of constitutional democracies' unilaterally enacted regimes of immigration law.

61. Raz, Authority of Law, supra note 50 at 262.

62. Applbaum, Ethics for Adversaries, supra note 49 at $69-70$. These bad systemic effects may well be the result of unwarranted reactions by the public; nonetheless, they should be taken into account in nonideal political action.

63. Here I follow Rawls, A Theory of Justice, supra note 1 at 373.

64. On the significance of expected effectiveness in nonideal political action, see Rawls, Law of Peoples, supra note 25 at 89. Contrary to Rawls's earlier suggestion that those who undertake 
general criteria, an additional constraint applies to public officials: they should only engage in civil disobedience if the urgency of opposing the immigration injustice being targeted for reform, and the boost to prospects for reform that their participation in civil disobedience is expected to provide, together outweigh the systemic risks their actions may pose to their state's democratic institutions.

\section{Conclusion}

I have examined the conditions under which would-be migrants to, as well as current citizens of, a constitutional democracy would be morally justified in nonviolently breaching its primary and secondary immigration laws respectively. I have argued that, contrary to the most developed account available, the injustice of an immigration law is not always sufficient to make mere noncompliance morally justifiable. The regimes of primary and secondary immigration law enacted by a constitutional democracy normally have legitimate authority, such that the subjects of these legal regimes have a presumptive moral duty to comply, even with immigration laws that are unjust to some degree. Noncompliance - even mere noncompliance - with immigration laws is justifiable only for particular laws that are tainted by some legitimacy-defeating feature, such as egregious injustice.

I stress, however, that my arguments should in no way be interpreted as a counsel of moral complacency. Firstly, many existing states claiming to be, or that are conventionally thought to be, constitutional democracies do not in fact meet even the minimal criteria to be properly judged as such. My claims about the legitimate authority of immigration law do not apply to the immigration law of such states. Secondly, many states among those that arguably do satisfy the criteria to be genuine constitutional democracies maintain highly restrictive regimes of immigration law that exclude refugees and others who have a human rights-based claim to be admitted. This egregious injustice is, I have suggested, a legitimacy-defeating condition. My account thus implies that mere noncompliance with the actual immigration law of even bona fide constitutional democracies will frequently be justified. Moreover, nothing I have said should be taken to suggest that individuals should meet unjust immigration laws with passivity. On the contrary, citizens have a moral imperative to contest such laws-including, in appropriate circumstances, by engaging in civil disobedience.

expectably counterproductive acts of civil disobedience are merely "acting unwisely," my claim is that their acts are morally unjustified (Rawls, A Theory of Justice, supra note 1 at 376). 